\title{
OLLI JÄRVINEN 1950-1990
}

Ornitologikokouksen avajaispäivän aamiaispöydässä Christchurchissa odotin tapaavani Sinut, mutta sainkin viestin äkillisestä kuolemastasi. Kesä muuttui räntäiseksi syksyksi.

Mitä me muut voimme tehdä tai sanoa, kun joku lähtee? Muisti on ilmiöistä epäluotettavin, mutta muutakaan meillä ei ole. Käymme siis läpi mielemme tallentamia kuvia, kaikki niistä yhtä tärkeitä tai yhtä merkityksettömiä.

Muistini tavoittaa kouluajat. Pitkät keskustelumme, joilla etsimme mieltä tuntien ja päivien pirstaleiseen, pitkäveteiseen seuraantoon. — Ja löysimme jyvän, jonka arvo on säilynyt: luonnon, suhteemme luontoon. Siinä ankkuri! — Mutta toki huomasimme, että ankkuri ei ollut järin luja, että ankkuriketjun ympärillä hääri nävertäjien armeijakunta.

Meidän oli siis saatava selville, miksi luontoa koko ajan ja kaikkialla tuhotaan, häikäilemättömästi, järjettömästi, tarkoituksettomasti. Ja meidän oli tehtävä jotakin. Etsimme ja luimme tärkeät kirjat Henry David Thoreau'sta ja Bertrand Russellista Engelsiin ja Marxiin. Ja keskustelumme jatkuivat.

70-lukumme olivat koko lailla erilaisia. Sinä löysit toiminnallesi perustan tutkimuksesta, loistavin tuloksin, kuten kaikki nopeasti oivalsimme. Olin hetkittäin jälkikäteen ratkaisustasi kateellinen, mutta tämä oli ilmiselvän hedelmätöntä: kukapa voisi luopua omien erehdystensä rakkaista opetuksista. Koko ajan keskustelumme jatkuivat. Tämä on tärkeää.

Tutkijaliiton ja Tiede \& edistyksen vuosikymmenellä aloimme taas syventyä yhteisiin teemoihimme: luonnonsuojelu ja sen tiedolliset perusteet; ekologia ja sen teoreettiset ongelmat; tiede ja sen kulttuuriset ulottuvuudet; tutkimus ja sen yhteiskunnalliset määritykset. Ja aina oli tietysti ikivanha yhteinen teemamme, linnut.

Sait käsittämättömän paljon tehdyksi suomalaisen ekologian, tieteen, luonnonsuojelun hyväksi; teit työtäsi alusta alkaen kansainvälisenä. Työsi ulottuvuuksia voimme vain aavistella. Mutta mikä Sinut mursi? Liika työ on pinnallinen selitys. Jouduitko sittenkin kiedotuksi maailmoihin, joissa työn laatua ei arvosteta, joissa tärkeätä on muodollinen oleminen, ei sisältöjen luominen, joissa keskinkertaisuudet ovat elementissään? Olitko niissä maailmoissa liian yksin?

John Berger kirjoitti Picassosta jotenkin siihen tapaan, että porvarillinen yhteiskunta antoi hänelle kaiken minkä se kykeni antamaan, mutta mikään siitä ei ollut vastaanottamisen arvoista. — Me puhuimme tästä kerran, yhteisellä 80-luvullamme.

Minä muistan keskustelumme, yhteiset tekemisemme, aina; kuten me kaikki.

Poissaolijat ovat läsnä ystäviensä ajatuksissa ja töissä. Olli, Sinä olet läsnä pitkään. 